\title{
Colleagues. Community. Collaboration. ACRL benefits you
}

A CRL strives to position academic and research libraries and librarians as indispensable to advancing learning and scholarship. We know ACRL members have a strong desire to learn and succeed, and we are dedicated to helping members become flexible, dynamic, and entrepreneurial leaders in their institutions and scholarly communities.

Each week we interview ACRL members to discover why they join (and what they value). Visit the ACRL Insider blog (www.acrl.ala.org /acrlinsider/category/member-of-the-week/) to read more personal statements about the value of academic and research librarianship and ACRL membership.

\section{Professional posse: ACRL brings us together}

Almost 12,000 academic and research librarians call ACRL home. ACRL brings talented and highly motivated members together by providing critical connections to people, opportunities, and resources. "I couldn't be more pleased with the warm welcome I received upon joining ACRL and the strong sense of community among its membership."

As one member said, "ACRL has provided great opportunities to work with others that share my interests. It's been simple to become directly involved."

\section{Professional development: Your community of practice}

According to a recent membership survey, the most valued personal benefit is learning. As engaged professionals, ACRL members benefit from professional development, opportunities to network, and access to current knowledge and research. ACRL provides opportunities to advance through research, publication, teaching, and service. Members value the growth and leadership opportunities provided by ACRL. Our publications, including CERL News, CERL, RBM, Choice, books, standards, and blogs, allow members to keep up with (and advance) the field. Our governance structure provides opportunities to lead, create, and shape the profession.

Through professional development programs, conferences, publications, e-learning, discussion lists, and committee service, ACRL provides a supportive infrastructure for each member to achieve a high level of continuous learning and achievement. "I've come to really love all the professional development opportunities that can be had, on the cheap, through ACRL."

"I joined ACRL as a step forward in my own professional development as a library student. I'm excited about the possibilities for collaboration and sharing that being part of a professional organization can bring about and inspire."

But wait-there's more! ACRL is dedicated to developing members who are recognized as leaders in their institutions and in scholarly communities. The higher education community benefits from the ongoing growth and development of academic/research librarians. Institutional enhancement represents the ultimate return on your membership investment: "ACRL membership is not just for you, but for your library."

Mary Jane Petrowski is ACRL associate director, e-mail: mpetrowski@ala.org

() 2010 Mary Jane Petrowski 


\section{Why "really smart librarians" belong to ACRL}

"My reason for joining ACRL has stayed my reason for continuing to be a member of ACRL: opportunity. The opportunity to work on projects that build my professional skill set. The opportunity to stay not only informed about, but also involved in, emerging professional trends.-Randy Hensley, head of instruction, Baruch College

"I joined ACRL as much to show my support for the organization as to gain support from the organization. ACRL is clearly an organization of deep-thinking, committed people who understand the issues that are unique to academic libraries."-Beth Evans, associate professor, Brooklyn College

"My interest in giving back to the profession and sharing some of my experiences with newer librarians, as well as continuing to learn, has kept me coming back."-Ann Marie Casey, library director, Embry-Riddle Aeronautical University

"I knew almost immediately in graduate school that I wanted to be a part of an association that fosters collegiality and communication among academic librarians. ACRL is definitely that group!"-Melissa Mallon, libraryinstruction coordinator/reference librarian, University of Pittsburgh-Johnstown

"One of my first instructors emphasized the importance of joining associations and volunteering as a way to learn and contribute. I joined ACRL to connect and network with other academic librarians and to contribute to the field."-Allison Miller, ip/2 Reference Services, Drexel University iSchool.

"When I was a brand new academic librarian, I joined because I figured it would look good on my C.V.! But after I started actually doing librarianship, I realized that ACRL is a great resource for my further growth in the field." - Cliff Landis, Web services librarian, Georgia State University

"I wanted to get involved in the profession, meet colleagues across the country and around the world, and learn how to do my job better. And ACRL has given me all those things." - Karen Munro, head, library and learning commons, University of Oregon

\section{Professional common ground: perfect for networking}

Members can meet and learn from other librarians who share their interests, virtually or face-to-face. ACRL brings all members into the wider community of academic librarianship through communities of practice, discussion lists, national conferences, and publications. The sharing of experience and expertise among members creates an inclusive, vital, and supportive channel that facilitates networking and collaboration.

"I joined ACRL due to my interest in academic librarianship. However, I stay a current member due to the personal and professional connections I have made through the association."

\section{Keeping up with constant change}

Members look to ACRL to keep them informed of issues, trends, and effective practices. ACRL guidelines, standards, research, statistics, and toolkits keep members in the know. Members also share information via ACRL discussion lists, blogs, wikis, podcasts, online communities, and publications.

As one member noted, "ACRL offered those of us who were new to librarianship a wide variety of resources on which to lean as we made our way in this demanding profession."

\section{ACRL: exceptional knowledge, resources, connections}

ACRL membership demonstrates solidarity and support for the profession as well as the work of ACRL in developing standards and guidelines for the profession. As a member, you support the voice of academic and research librarians in higher education as well as in the library community. Increase your effectiveness, value, and connection to the profession through ACRL. We will help you connect, contribute, and keep current.

Membership application forms are available online at www.acrl.org. Join today and become part of a "life-changing organization," a wonderful community of academic librarians who are dedicated to the profession and willing to share their wisdom and experience. $\boldsymbol{n}$ 